REVIEW PAPER

\title{
SORGHUM AS SOURCE OF FUNCTIONAL COMPOUNDS AND THEIR IMPORTANCE IN HUMAN NUTRITION
}

\author{
DANIELA IONELA ISTRATI ${ }^{\mathrm{a}}$, OANA EMILIA CONSTANTIN ${ }^{\mathrm{a}}$, CAMELIA VIZIREANU $^{\mathrm{a}}$, \\ DINICA RODICA ${ }^{\mathrm{b}}$, BIANCA FURDUI ${ }^{\mathrm{b}^{*}}$ \\ aUniversity "Dunărea de Jos" of Galati, Faculty of Food Science and Engineering, no.111, \\ Domneasca str., 800201, Galati, Romania \\ ${ }^{b}$ University “Dunărea de Jos” of Galati, Faculty of Science and Environment, no.111, \\ Domneasca str., 800201, Galati, Romania \\ *corresponding author: bianca.furdui@ugal.ro
}

Received on $18^{\text {th }}$ November 2019

Revised on $26^{\text {th }}$ November 2019

\begin{abstract}
Due to the progress made in preventive medicine, it has been possible to highlight the key role of nutrition in the prevention of diseases, especially those related to diet. The general concern for the development of functional foods has generated the need to study and use new food ingredients involved in maintaining and improving the health condition. Sorghum is one of the most important grain considering the cultivated land areas and global production. Also, sorghum is a gluten-free grain and a rich source of nutrients and biologically active compounds. In this context, sorghum has a huge potential for its exploitation and development of healthy and functional food products. Therefore, this review summarizes the information regarding the concept of the functional food, as well as the role of functional compounds which are found in food products, especially in sorghum grains, and beneficial effects on human health.
\end{abstract}

Keywords: functional foods, health, nutrients, fibers, antioxidants

\section{Introduction}

Food is an environmental factor indispensable to the human body. Its daily consumption is necessary to meet everyday needs. This intake takes place in the form of solid and liquid food. Foodstuff is complex, natural substances that have undergone a technological and/or culinary treatment, preserved with or without special treatment (Opopol et al., 2006).

Lately, an increase in terms of consumer interest in the importance of healthy food or physiologically active specific components called functional food was registered (Hasler, 1998).

The term functional food was introduced by Japanese researchers in 1984, who studied the relationship between nutrition, sensory satisfaction, fortification, and

https://doi.org/10.35219/foodtechnology.2019.2.13 
modulation of physiological systems. Different definitions of functional food can be found around the world, but there is no official definition. Therefore, a functional food product can be a natural food, a food product where a component was added to or out of which a component was removed, a food including one or more components whose nature was altered or any combination of these possibilities (Wang and $\mathrm{Li}, 2014$ ). Functional food products can offer health benefits when consumed at adequate levels in a regular diet (Sharanya Rani and Penchalaraju, 2016). The functionality of food may be similar for all individuals or for a specific population, defined, for example, by age or genetic structure. Moreover, functional foods, in addition to their primary nutritional effect, also have a positive influence on the functions of the human body (improvement of general physical condition, reduction of disease risk, etc.) (Roberfroid, 2000, Howlett, 2008; Ozen et al., 2012).

Up to date, Japan is the only country that has formulated a system of standards and registration and approval specifications for functional foodstuff, known as Foods for Specified Health Use (FOSHU). These food products are eligible to carry a seal of approval from the Japanese Ministry of Health and Social Protection (Arai, 1996). At present, 100 products are licensed as FOSHU foods in Japan.

The European Commission's Concerted Action on Functional Food Science in Europe (FUFOSE) has defined functional foods as follows: "A nutrient can easily be considered a functional food only if it was satisfactorily proven that one or more target functions can be changed positively, in addition to nutritional effects, to constantly improve health and well-being while reducing the risk of any illness. A functional food should ideally be a nutrient and should not change its efficacy when it enters a diet; it should not be a pill or capsule" (Scientific Concepts of Functional Foods in Europe). The same committee concluded that basically, functional food could be one of the following:

- a natural food;

- a food product with an addition of one component added;

- a food that no longer contains one of the components;

- a food product in which one or more components have been changed;

- a food product in which the bioavailability of one or more components has been modified;

- any combination of the previous features.

Worldwide, a relatively large number of terms are used to define natural products developed for health benefits: functional foods, nutraceuticals, pharmafood, designer food, vitafood, and foodceuticals (Roberfroid, 2000; Constantin and Istrati, 2018).

Current foods incorporate a growing volume of technical and scientific progress. As a result, modern food technology is distinct from the classical one. The critical areas for the technological challenges that were identified are as follows: 
- creating new functional nutritional elements out of traditional raw materials;

- optimizing functional nutrients out of raw materials and foods - for instance: preservation or maximum retention of elements;

- altering their function and their high bioavailability;

- monitoring of the quantity and effectiveness of functional nutrients in the raw materials and food.

Irrespective of the production technology, foods are made up of several basic ingredients, called nutrients that fall into two categories:

- macronutrients in the broad sense: proteins, lipids, carbohydrates, some minerals, the intake of which is indispensable in significant quantities (in the tens of grams or even grams per day);

- micronutrients (most of the vitamins and minerals, the intake of which is in the range of micrograms or milligrams per day).

Macronutrients consist most often in large molecules and complex structures that require a prior breakdown (digestion) into molecules that are small enough and simple to be absorbed. Proteins are sources of amino acids, lipids - fatty acids, cholesterol, glycerol, etc.; complex carbohydrates are sources of monosaccharides, like glucose, galactose, fructose, xylose and its derivatives, such as the sorbitol, etc. Proteins, carbohydrates, and lipids are "nutrient source molecules" and are absorbed after preliminary digestion. Amino acids, fatty acids, cholesterol, various monosaccharides, vitamins, and minerals are considered "cell nutrients" and are absorbed directly without prior digestion (Opopol et al., 2006).

The nutrient content gives the nutritional value of foods, along with their quality, bioavailability, and the way consumers are physically satisfied (Segal, 2002). In addition to macronutrients, the human body also needs other components of nutritional interest: food fibres and various compounds such as tannins, phenolic compounds, various organic acids (that are to be found mainly in vegetables) that can exert an influence on digestion, absorption and sometimes on the metabolism of nutrients (Opopol et al., 2006).

Therefore, functional foods are products that contain various biologically active compounds and which - provided that they are consumed in a current diet contribute to maintaining the optimal state of physical and mental health of the population.

Recent epidemiological studies demonstrated the beneficial effect of whole grains and cereal products on medical conditions such as type II diabetes, obesity, coronary heart disease, cardiac disease, and certain cancers (McCarty, 2005, Yu and Nanguet, 2013). Cereals and grain products cover about $50 \%$ of the daily energy required for a person. This nutritional intake can provide $50 \%$ of the daily protein requirement, $25 \%$ calcium, $50 \%$ iron, and $40 \%$ vitamin B (USDA, 2019). 
Sorghum (Sorghum bicolor) is a cereal that belongs to the Gramineae family being cultivated for the first time about 4000 years ago in North-East Africa (Rooney and Waniska, 2000). There are several varieties of sorghum from white to yellow, brown, red and black. Sorghum is one of the most important cereals in the world, ranking fifth in terms of global cereal production by corn, wheat, rice, and barley. In 2017 the annual production quantity of sorghum was estimated to be 57.6 million tons grain from an area harvested of 42.67 million hectares (FAO, 2017).

Researches have shown that sorghum whole grains have substantial health benefits as a result of its high nutritional value and to the unique profile of phenolic compounds (Khan et al., 2015; Khoddami et al., 2015, Rao et al., 2018, Xiong et al., 2019). The variations of climatic conditions during the growing period of the crop along with crop varieties, soil type, fertilizers and method of fertilization influence the chemical and nutritional composition of sorghum (Ebadi et al., 2005). According to USDA (2019), 100g of sorghum grain contains on average $10.6 \mathrm{~g}$ proteins, $72.09 \mathrm{~g}$ carbohydrates, $6.7 \mathrm{~g}$ fibers, $3.46 \mathrm{~g}$ lipids and provides $1377 \mathrm{~kJ}$ energy. The unusual composition of sorghum phenolic compounds (phenolic acids, 3-deoxyanthocyanins, flavones, flavanones, and condensed tannins) and their high level reported in sorghum bran, make sorghum an interesting cereal for the production of healthy functional foods, as a source of bioactive compounds.

\section{The functional role of proteins within human nutrition}

Proteins are the fundamental constituents of living cells. Growth, reproduction, and nutrition, which are essential functions of the living matter, are related to proteins and their metabolism products: peptides and amino acids (Shang et al., 2018; Opopol et al., 2006). Therefore, proteins have various functions, such as:

- structural role, as components of all the cells, necessary to growing and restoring tissues ;

- taking part in metabolic processes, in regulating the hydro-electrolytic and the acid-base balance, they are structural components of various enzymes and hormones and thus have a functional role. They can also perform specific functions - antibodies;

- energetic role.

Proteins of animal origin are more equilibrated in indispensable amino acid content in comparison to proteins of vegetable origin. In terms of the indispensable amino acid content, proteins are divided into three categories:

A. proteins with superior biological value - which contain all essential amino acids in adequate proportion to the human body (most of the animal proteins);

B. medium-quality proteins - which also contain all essential amino acids, but some in insufficient proportions (vegetables, fruits, dried legumes, cereals); 
C. low biological value proteins lacking one or more essential amino acids (for example zein, the main maize protein, is depleted of lysine and very poor in tryptophan, while collagen is tryptophan-free, low methionine, isoleucine, lysine, and threonine) (Damtie, 2019; Paul et al., 2019; Murano, 2003).

The required amount of protein depends on the needs of the body's development and their biological value, according to the diet. The recommended intake is based on the amount of protein required to maintain the balance between the amount of nitrogen consumed as protein and the nitrogen eliminated daily.

The total protein intake should be $10-15 \%$ (20\% maximum) of the total calories with a optimal dietary protein intake for adult people of $0.66 \mathrm{~g}$ protein $/ \mathrm{kg} /$ day and for older people a optimal dietary protein intake of $1.2 \mathrm{~g}$ protein $/ \mathrm{kg} /$ day (Rand et al., 2003; FAO, 2013; Bauer et al., 2013).

The protein deficiency leads to a drop in the metabolic capacity, to reduced energy metabolism, to the inhibition of biosynthesis processes, to a diminished immunity, and body resistance to external agent actions, accordingly. Usually, the required protein is influenced by gender, age, activity level, and body health or physiological condition (Wolfe et al., 2017; Dullius et al., 2018). Conventional sources of protein are products of animal and plant origin such as meat, milk, eggs, fish, cereals, etc. (Dullius et al., 2018).

Sorghum proteins can be divided into two categories: prolamine proteins (kafirins are the main form of protein storage in sorghum grain and represents about $80 \%$ of total protein) and non-prolamine proteins (globulins, glutelins, and albumins which represent $20 \%$ of total protein). Depending on the molecular weight, there are four types of kafirins $\alpha-, \beta-, \gamma-$, and $\delta$-kafirin. Sorghum prolamines are characterized by a high content of glutamic acid, leucine, alanine, proline, and by a low content of lysine, which represents only $0.2 \%$ of the total amino acids (Serna-Saldivar and Rooney, 1995; Xiong et al., 2019; UDSA, 2019). However, sorghum lysine deficiency can be ameliorated by breeding or fortification (Henley et al., 2010; Grootboom, 2010).

Sorghum proteins are characterized by reduced digestibility because kafirins have high levels of polymerization and extensive disulfide bridges which are resistant to enzymatic digestion. Also, the interaction of sorghum proteins with tannins and starch leads to decreased digestion. Due to the low digestibility of starch and protein, sorghum can be used as a food source for people with obesity and diabetes. Moreover, kafirin (as a gluten-free ingredient) is used to develop healthy food products for people with celiac disease (Belton et al., 2006).

\section{The functional role of bioactive lipids in human nutrition}

Lipids are a family of water-insoluble compounds with particular properties, determined by the structure and the physio-chemical characteristics of the various molecules in their composition. Lipids play essential roles in the body, particularly in maintaining the integrity of cell membranes, in nervous transmission, and in the 
process of absorbing nutrients. Food lipids are composed of esterified fatty acid molecules in the form of triglycerides and phospholipids. Food sterols are mainly represented by cholesterol and sterols of plant origin (phytosterols).

On the other hand, depending on the hydrogen saturation of their molecule, fatty acids are classified as saturated and unsaturated. Unsaturated fatty acids may be mono - or polyunsaturated. Fats of animal origin contain more saturated fatty acids, and those of vegetable origin have unsaturated fatty acids, the latter showing cardiovascular protective properties. Cholesterol is a necessary substance for the body and is found only in foods of animal origin, but it can also be synthesized in the body.

The investigations conducted to elucidate the role of lipids in human food showed that these nutrients possess first-order biological properties due to their intake in biologically active compounds such as polyunsaturated fatty acids, phosphatides, sterides, vitamins D, etc. (Segal, 2002). Besides the role of the lipid as a highcalorie source, structural constituents of biomembranes or as solvents and vehicles of lipid-soluble vitamins, are important by their intake of polyunsaturated fatty acids, phosphatides and physiologically active substances such as prostaglandins, prostacyclins, etc. (Hansen, 1994). It is already known that the polyunsaturated fatty acids (omega-3 and omega-6) are essential for human health and are exclusively obtained from food (Rubio-Rodríguez et al., 2010). In recent years, the importance of making functional foods supplemented with n-3 fatty acids was highlighted. There is currently a wide range of omega-3-enriched foods such as bakery products, dairy products, soft drinks and juices, meat products, etc. (Kolanowski and Laufenberg, 2006). Typically, the natural sources of n-3 fatty acids are some seeds and fish oils (Rubio-Rodríguez et al., 2010; JiménezColmenero, 2007).

Healthy eating should not contain a lipid contribution of more than $30 \%$ of the total daily energy intake. Of these, less than $10 \%$ will be provided by saturated fatty acids, $10 \%$ by the monounsaturated fatty acids, and $10 \%$ by the polyunsaturated fatty acids as cis. During the last decade, the scientific studies concluded that consumption of 1-2 g/day of polyunsaturated fatty acids is required for maintaining the state of health. It was shown that polyunsaturated fatty acids have a beneficial effect in some diseases, such as rheumatoid arthritis and atopic dermatitis (FAO, 2010; Hooper et al., 2015).

Sorghum lipids consist mainly of unsaturated fatty acids, of which the most abundant are polyunsaturated (monounsaturated fatty acids represent $1.131 \mathrm{~g} / 100 \mathrm{~g}$ and polyunsaturated fatty acids $1.558 \mathrm{~g} / 100 \mathrm{~g}$ ). The main sorghum fatty acids are oleic, palmitic, linoleic, stearic, and linolenic (Adeyeye and Ajewole, 1992; USDA, 2019). Sorghum lipids such as phytosterols and polycosanols were shown to protect against cardiovascular disease by regulating cholesterol metabolism (Carr et al., 2005; Hoi et al., 2009; Martınez et al., 2009). 


\section{The functional role of vitamins and minerals in human nutrition}

Vitamins are organic compounds with a complex structure that cannot be synthesized by the human body. Their presence in the body is essential for the fulfilment of essential functions of the body. Vitamins are required in minimal amounts for the normal development of many metabolic processes, including assimilation and use of nutrients, food growth, and tissue restoration (Gould, 1995). Unlike proteins, lipids or carbohydrates, vitamins are not sources of calories and are needed in much smaller quantities. Depending on how they are dissolved in various solutions, vitamins are classified into liposoluble (vitamins $\mathrm{A}, \mathrm{D}, \mathrm{E}$, and $\mathrm{K}$ ) and water-soluble (vitamins falling into group B and vitamin C). Water-soluble vitamins are particularly useful in energy-releasing reactions, and liposoluble ones are more involved in metabolic processes and the formation of certain bodyspecific substances (Segal, 2002).

Sources of vitamin B1 are germs of cereals, nuts, whole grains, beer yeast, etc. Vitamin B1 has several essential functions in the body, such as: maintaining a regular appetite and digestion, also useful in terms of growth and lactation (Gould, 1995). Vitamin B2 (riboflavin) is found in bakery yeast, eggs, meat, fish, and dairy products. In the human body, riboflavin performs specific metabolic functions in the glucose metabolism (glucose and galactose are rapidly absorbed only in the presence of riboflavin) but also in the lipid and amino acid metabolism (Combs and McClung, 2016). Vitamin B5 is found in wheat germ, oats, broccoli, mushrooms, cauliflower, dried peas, soybeans, etc. As coenzyme A, riboflavin has a vital function in different metabolic pathways, such as carbohydrates and lipids metabolism (Combs and McClung, 2016). Vitamin B6 participates as a coenzyme in the form of pyridoxine and pyridoxal to the activity of transaminases, having an important role in the metabolism of amino acids. Pyridoxal and pyridoxamine are coenzymes involved in transamination, decarboxylation, melanin formation, tryptophan metabolism, transmethylation, porphyrin synthesis, and others (Saghiri et al., 2017). Important sources of vitamin B6 are meat, liver, fish, beans, nuts, baker's yeast (Saccharomyces cerevisiae), cereals, etc.

Vitamins E (tocopherol) exerts more functions in the body by participating in the proper functioning of specific apparatuses and systems such as the reproductive, the cardiovascular, and the muscular one. It is also a biological antioxidant for oxidable vitamins and lipids (Combs and McClung, 2016). High amount of vitamin $\mathrm{E}$ are found in vegetable oils, cereal-based products, and eggs.

Vitamin C (ascorbic acid) plays a significant biological role, its field of activity being wide to such an extent that it can be appreciated that there is no essential physiological or metabolic process to which it does not participate (Segal, 2002). Vitamin $C$ acts as a biochemical antioxidant (Combs and McClung, 2016), interfering with many processes, including protein metabolism, stromal protein formation (collagen, elastin), carbohydrate metabolism (it inhibits cholesterol synthesis and prevents the development of atherosclerosis), lipid metabolism (reduces blood cholesterol), etc. Sources rich in vitamin C include vegetable products such as citruses, tomatoes and tomato juice, cabbage, parsley, nettle, 
spinach, cauliflower, red and green peppers, red cabbage, eggplants, broccoli, strawberries, (Saghiri et al., 2017; Sinha et al., 1993).

Minerals are inorganic substances with a simple structure (non-fractional), which the body has to acquire from food because it cannot synthesize them as such. As with vitamins, minerals perform essential functions in the human body without being sources of calories and are needed in much lesser amounts than proteins, lipids, or sugars (Ihnat, 2003)

The mineral substances necessary to the body can be classified into two categories of macroelements (found in the body in considerable quantities: calcium, phosphorus, magnesium, sulfur, chlorine, potassium and sodium) and microelements or trace elements (found in small or extremely small quantities: iron, copper, chromium, manganese, zinc, cobalt, molybdenum, nickel, tin, silica, arsenic, selenium, fluoride and iodine). The distribution of minerals in food is irregular. Some minerals, like potassium and sulfur, are abundantly spread in the food, so a varied diet always contributes sufficiently.

Mineral elements have a critical biological role considering that they participate in all the vital processes of the body. Mineral substances may have different roles in the vitamin and enzymes operation, either having an activating role (calcium, magnesium, etc.) or an inhibiting role (copper) and may be part of the specific enzyme structure (sulfur, iron, copper, etc.) or non-specific elements (magnesium, zinc, cobalt, etc.) (Hathcock, 1997).

From the whole vitamins mentioned above, the principal vitamins in sorghum grains are B complex vitamins that play a major role in energy metabolism (thiamin, pyridoxine, and riboflavin), and alpha-tocopherol. Moreover, sorghum is a good source of minerals whose bioavailability varies from less than $1 \%$ for $\mathrm{Fe}$ to over $90 \%$ for $\mathrm{K}$ and $\mathrm{Na}$. Therefore, the main minerals in sorghum are potassium, phosphorus, magnesium, and zinc (Leder, 2004; Ratnavathi and Patil, 2013; USDA, 2019). Compared to rye and barley, sorghum has a lower composition in $P$, $\mathrm{Mg}, \mathrm{K}, \mathrm{Na}, \mathrm{Ca}, \mathrm{Fe}, \mathrm{Zn}, \mathrm{Mn}$, and $\mathrm{Cu}$, similar to millet (Ragaee et al., 2006). Worldwide there are four micronutrients at risk, which represent a problem of human nutrition, namely iron, zinc, iodine, and vitamin A. Sorghum is a good source of iron and zinc and can be used in programs to combat malnutrition in the population of developing countries (Nguni et al., 2011).

\section{The functional role of dietary fibers in human nutrition}

According to Regulation (EU) No. 1169/2011, the term "fibers" refers to carbohydrate polymers formed of three or more monomeric units that cannot be digested or absorbed at human small intestine level. They belong to the following categories:

1. carbohydrate polymers naturally occurring in foods;

2. carbohydrate polymers obtained from food raw materials by physical, enzymatic or chemical methods;

3. synthetic edible carbohydrate polymers with beneficial physiological effect demonstrated by generally accepted scientific evidence. 
Food fibers have many beneficial effects on health: reducing the intestinal transit time, diminishing the total cholesterol and/or LDL levels in the blood, reducing postprandial blood sugar and/or insulin levels, etc (Mehta, 2005). Because of these effects, they can prevent colon cancer, diabetes, constipation, ischemic heart disease, myocardial infarction, obesity, dental caries (Cade and Burley, 2007; Spotti and Campanella, 2017), improve gastrointestinal health and reduce sensitivity to certain diseases. Increased consumption was also associated with increased satiety and weight loss (Georgescu, 2004). The recommended fiber intake should be 20-30 $\mathrm{g} /$ day. Ingestions higher than $30 \mathrm{~g}$ /day may cause disturbances accompanied by bloating and abdominal pain (Opopol et al., 2006).

Rich sources of fiber are whole grains, dried peas, beans, vegetables, nuts, and fruits. Sorghum is an excellent source of dietary fiber ranging from $6 \mathrm{~g}$ to 8.6g/100g (USDA, 2019). According to Awika et al. (2005), the dietary fiber content of the cereals is about $45 \%$ in the bran and represents up to 6 times more than the level measured in the endosperm. Therefore, fractions of sorghum bran contain on average $36-50 \%$ total dietary fiber from which $35-48 \%$ insoluble dietary fiber (Rooney et al., 1992). In studies conducted to obtain functional food products (such as bread, cakes, and expanded snacks) with the addition of sorghum bran, it was shown that it confers an attractive natural color with no negative impact on other sensory properties of foods (Gordon, 2001; Acosta et al., 2003). Dietary fibers from sorghum may play a crucial role in the development of healthy food products due to the growing need for diversification of functional foods (Miafo et al., 2015).

\section{The functional role of polyphenols in human nutrition}

Polyphenols are one of the most common and widespread groups of herbal substances that appear in all vegetative organs. These are secondary metabolites in plants, in response to ultraviolet rays, to the aggression of pathogens (Beckman, 2000). More than 8.000 phenolic structures out of which more than 4.000 flavonoids (Harborne, 2000; Cheynier, 2005) were identified by now.

Classification of polyphenols was quite difficult to achieve due to the large variety of these compounds. Tsao (2010) gave the most common classification according to the chemical structure: phenolic acids, flavonoids, stilbens, and ligands, while Shalaby and Shanab (2013) gave a different classification as following: flavonoids and phenolic acids. Flavonoids are polyphenolic compounds, including two benzene rings connected by a "bridge". The main subclasses of these compounds are flavones, flavonols, flavan-3-ethanol, isoflavones, flavanones, and anthocyanidins. Other groups of flavonoids, which are smaller food components, are chalcones, dihydrochalcones, dihydroflavonols, flavan-3,4-diols, coumarins, and aurones (Del Rio, 2013). The main subclasses of phenolic acids are hydroxicinnamic and hydroxibenzoic acids (Shalaby and Shanab, 2013).

Polyphenols and flavonoids have proved to have many beneficial effects on health: antioxidant and free radicals capturing property, anti-atherosclerotic, cardioprotective, neuroprotective, anti-aging, anti-neurodegenerative, anti-inflammatory, 
anti-mutagenic, anti-cancer, improving endothelial function, anti-allergic, antidiabetic, anti-bacterial and hepato-protective function (Han et al., 2007).

Sorghum contains both phenolic acids and flavonoids, which are found in pericarp, testa, and endosperm. Phenolic acids in the sorghum grains are found in bound (70-95\% of the phenolic acids are associated with polysaccharides from the cell wall) and free forms. Free phenolic acids aren`t linked with the cell wall and are found especially in pericarp and testa. They often conjugate with glycerol and carbohydrates (Svensson et al., 2010; Taylor et al., 2014). The most important phenolic acids reported in sorghum are vanillic, gallic, cinnamic, protocatechuic, $\mathrm{p}$ coumaric, syringic, p-hydroxybenzoic, caffeic, ferulic, and sinapic acids (Althwab et al., 2015; Vanamala et al., 2018).

Flavonoids are the most abundant phenolic compounds reported in sorghum. These compounds are found mostly in bran and are responsible for pericarp color and pigmented testa. The main flavonoids reported in sorghum are anthocyanins (3deoxyanthocyanidins), flavones, and flavanones which are more abundant, and flavan-3-ols, flavan-4-ols, flavonols, and dihydroflavonols (Dykes et al., 2005; Awika et al., 2005; de Morais Cardoso et al., 2017; Shen et al., 2018). Of the flavonoid class, anthocyanins are the most studied, due to their unique structure that gives them special properties. The main anthocyanins found in sorghum - 3deoxyanthianine doesn't contain the hydroxyl group at position 3 of the $\mathrm{C}$ ring. This unique feature leads to increased stability of 3-deoxyanthianine at high $\mathrm{pH}$ values which makes them usable in the food industry in the form of natural food colorants. The most important 3-deoxyananthocyanidins in sorghum are apigeninidine (responsible for the yellow color) and luteolinidine (responsible for the orange color) (Awika et al., 2004). The highest quantity of 3-deoxyanthianine is found in sorghum bran. Studies have reported contents up to five time higher of 3-deoxyanthianine in bran compared to whole grain. In some types of sorghum, the 3-deoxyanthianine content represents over $80 \%$ of the total amount of flavonoids. Moreover, of the sorghum genotypes, the black sorghum bran contains the highest amount of 3-deoxyanthianine $(4,700-16,000 \mu \mathrm{g} / \mathrm{g})$ as compared to the red (14-680 $\mu \mathrm{g} / \mathrm{g}$ ) and the brown one $(3,600 \mu \mathrm{g} / \mathrm{g})$ or with other cereals (blue barley $4 \mu \mathrm{g} / \mathrm{g}$, $\mathrm{red} /$ purple maize 225-965, blue/purple wheat grain 35-507 $\mu \mathrm{g} / \mathrm{g}$ or black rice 158299 g/g (Awika et al., 2004; Awika et al., 2005; Abdel-Aal et al., 2008; Hiemori et al., 2009).

Besides ensuring an attractive color from orange to red, blue, and purple, 3deoxyanthianine has high antioxidant and antimicrobial properties with positive implications in human health. Sorghum is considered to be the main source of 3deoxyanthianine for humans (Awika et al., 2004; Awika et al., 2005; de Morais Cardoso et al., 2017).

Other intensively studied sorghum polyphenols are tannins (condensed tannins or proanthocyanidins) which have potential health benefits due to their antioxidant capacity. Tannins are mainly found in both pericarp and cell walls but their concentration differs depending on the variety of sorghum. Depending on the genotype of the sorghum as well as the concentration of tannins and their degree of 
extractability, sorghum can be classified into three categories: a) Sorghum type I has recessive genes (B1, B2), has no pigmented testa and therefore has no tannins or very small amounts (0 to $1.8 \mathrm{mg}$ CAE/g); b) Sorghum type II has the dominant $\mathrm{B} 1$ and $\mathrm{B} 2$ genes and recessive $\mathrm{S}$ genes, has pigmented testa with moderate amounts of tannins (6.4 to $15.5 \mathrm{mg} \mathrm{CAE} / \mathrm{g}$ ); and c) Sorghum type III has pigmented testa, all genes are dominant (B1, B2 and S), and high amounts of tannins (11 to $50.2 \mathrm{mg} \mathrm{CAE} / \mathrm{g}$ ) (Dykes and Rooney, 2006). According to Gu et al. (2004), the daily average dose of proanthocyanidins is estimated to be between 1.3 $\mathrm{mg} /$ day for infants, about $50 \mathrm{mg} /$ day for children and young people, and over 70 $\mathrm{mg} /$ day for the men over 60 years of age.

Compared with other cereals such as wheat, rice or maize, the phenolic compounds extracted from sorghum have the highest antioxidant activity, the values being comparable to those obtained by fruits or vegetables (Wu et al., 2004). The antioxidant activity of sorghum is strongly linked to the total content of phenolic compounds and especially the condensed tannin content that is higher in black and brown sorghum (Awika et al., 2005; Dykes et al., 2005).

The antioxidant activity of sorghum biological active compounds was correlated with many beneficial properties for human health such as reduced oxidative stress (Khan et al., 2015), anti-cancer (Yang et al., 2009; González-Montilla et al., 2012; Suganyadevi et al., 2013) anti-diabetic (Kim et al., 2011; Kim and Park, 2012), anti-microbial (Kil et al., 2009), and anti-inflammatory activity (Burdette et al., 2010).

\section{Conclusions}

Functional foods include foods that contain fatty acids, dietary fiber, vitamins, and minerals as well as foods with containing biologically active compounds such as polyphenols, which exhibit high antioxidant activity. Studies on functional foods confirm that nutrition has a significant impact on the prevention of chronic diseases since most of these foods are consumed daily. Sorghum is one of the most important global grain crops which have high nutritional values with positive impact on human health. Although traditionally sorghum was used to obtain different foods such as boiled products, baked foods, steamed or fermented beverages, nowadays, due to advanced food science and technologies, both whole sorghum grains and its valuable functional compounds (phenolic compounds, bran, 3-deoxyanthianine, etc.) can be used to obtain healthy and functional food products.

\section{Acknowledgments}

This work was supported by a grant of the Romanian Ministery of Research and Innovation, CCCDI-UEFISCDI, project number PN-III-P1-1.2-PCCDI-20170566/9PCCDI/2018, within PNCDI III. 


\section{References}

Abdel-Aal, E.S. M., Abou-Arab, A.A., Gamel, T.H., Hucl, P., Young, J.C., Rabalski, I. 2008. Fractionation of Blue Wheat Anthocyanin Compounds and Their Contribution to Antioxidant Properties. Journal of Agricultural and Food Chemistry. 56, 11171-11177.

Acosta, D., Barron, M., Riaz, M., Waniska, R., Rooney, L.W. 2003. Factors affecting extrusion of white sorghum to produce whole grain snacks. In AACC Annual Meeting, Portland OR, Sep.

Adeyeye, A., Ajewole, K. 1992. Chemical composition and fatty acid profiles of cereals in Nigeria. Food Chemistry, 44(1), 41-44.

Althwab, S., Carr, T.P., Weller, C.L., Dweikat, I.M., Schlegel, V. 2015. Advances in grain sorghum and its co-products as a human health promoting dietary system. Food Research International, 77, 349-359.

Arai, S. (1996). Studies on functional foods in Japan - state of the art. Bioscience, biotechnology, and biochemistry. 60(1), 9-15.

Awika, J.M., Rooney, L.W., Waniska, R.D. 2004. Properties of 3-deoxyanthocyanins from sorghum. Journal of Agricultural and Food Chemistry, 52(14), 4388-4394.

Awika, J.M., Rooney, L.W., Waniska, R.D. 2005. Anthocyanins from black sorghum and their antioxidant properties. Food Chemistry, 90(1-2), 293-301.

Bauer, J., Biolo, G., Cederholm, T., Cesari, M., Cruz-Jentoft, A.J., Morley, J.E., Visvanathan, R. 2013. Evidence-based recommendations for optimal dietary protein intake in older people: a position paper from the PROT-AGE Study Group. Journal of the American Medical Directors Association, 14(8), 542-559.

Beckman, C.H. 2000. Phenolic storing cells: keys to programmed cell death and periderm formation in wilt disease resistance and in general defense responses in plants? Physiological and Molecular Plant Pathology. 57, 101-110.

Belton, P.S., Taylor, J.R.N. 2004. Sorghum and millets: Protein sources for Africa. Trends in Food Science \& Technology, 15(2), 94-98.

Burdette, A., Garner, P.L., Mayer, E.P., Hargrove, J.L., Hartle, D.K., \& Greenspan, P. 2010. Anti-inflammatory activity of select sorghum (Sorghum bicolor) brans. Journal of Medicinal Food, 13(4), 879-887.

Cade, J, Burley, V. 2007. Dietary fibre and risk of breast cancer in the UK Women's Cohort Study. International Journal of Epidemiology, 36, 431 - 438.

Carr, T.P., Weller, C.L., Schlegel, V.L., Cuppett, S.L., Guderian, D.M.,Jr., Johnson, K.R. 2005. Grain sorghum lipid extract reduces cholesterol absorption and plasma non-HDL cholesterol concentration in hamsters. The Journal of Nutrition, 135(9), 2236-2240.

Cheynier, V. 2005. Polyphenols in foods are more complex than often thought. The American Journal of Clinical Nutrition, 81, 223S-229S.

Combs, G.F., McClung, J.P. 2016. The vitamins: fundamental aspects in nutrition and health. Academic press.

Constantin, O.E, Istrati, D.I., 2018. Functional Properties of Snack Bars. In Functional foods. Intech Open. London. U.K. 
Damtie Y. 2019. A review of improving the protein quality with the composition of quality traits of maize (Zea mays L.) grain and possible breeding techniques. Asian Journal of Plant Science and Research, 9(3), 1-12.

de Morais Cardoso, L., Pinheiro, S.S., Martino, H.S., Pinheiro-SantAna, H.M. 2017. Sorghum (Sorghum bicolor L.): Nutrients, bioactive compounds, and potential impact on human health. Critical Reviews in Food Science and Nutrition, 57(2), 372-390.

Del Rio, D.R.M. 2013. Dietary (poly) phenolics in human health: structures, bioavailability, and evidence of protective effects against chronic diseases. Antioxidants \& Redox Signaling, 18(4), 1818-1891.

Dullius, A., Goettert, M.I., De Souza, C.F.V. 2018. Whey protein hydrolysates as a source of bioactive peptides for functional foods - biotechnological facilitation of industrial scale-up. Journal of Functional Foods, 42, 58-74.

Dykes, L., Rooney, L.W., Waniska, R.D., Rooney, W.L. 2005. Phenolic compounds and antioxidant activity of sorghum grains of varying genotypes. Journal of Agricultural and Food Chemistry, 53(17), 6813-6818.

Dykes, L., Rooney, L. W. 2006. Sorghum and millet phenols and antioxidants. Journal of Cereal Science, 44(3), 236-251.

Ebadi, M.R., Pourreza, J., Jamalian, J., Edriss, M.A., Samie, A.H., Mirhadi, S.A. 2005. Amino acid content and availability in low, medium and high tannin sorghum grain for poultry. International Journal of Poultry Science, 4(1), 27-31.

FAO. 2010. Fats and fatty acids in human nutrition. Report of an expert consultation, FAO Food and Nutrition Paper 91. Rome: Food and Agriculture Organization of the United Nations.

FAO (Food and Agriculture Organization). 2013. Dietary protein quality evaluation in human nutrition: report of an FAO Expert Consultation. Food and nutrition paper; 92. FAO: Rome.

FAO. 2017. FAOSTAT, Food and Agriculture Organization of the United Nation. Retrieved from http://www.fao.org/faostat/en/\#data/QC

Georgescu, L. 2004. Noi ingrediente funcţionale utilizabile în panificaţie. Buletin Informativ pentru Industria de Morărit şi Panificaţie, 15, 24-30.

González-Montilla, F.M., Chavez-Santoscoy, R.A., Gutierrez-Uribe, J.A., Serna-Saldivar, S.O. 2012. Isolation and identification of phase II enzyme inductors obtained from black Shawaya sorghum [Sorghum bicolor (L.) Moench] bran. Journal of Cereal Science, 55(2), 126-131.

Gordon, L.A. 2001. Utilization of sorghum brans and barley flour in bread (Doctoral dissertation, Texas A\&M University).

Gould, W.A. 1995. Glossary for the Food Industries, Woodhead Publishing.

Grootboom, A.W., 2010. Effect of RNAi Down-regulation of three lysine deficient kafirins on the seed lysine content of sorghum [Sorghum bicolor (L.) Moench]. PhD thesis. University of Pretoria, South Africa.

Gu, L., Kelm, M., Hammerstone, J., Beecher, G., Holden, J., Haytowitz, D., Gebhardt, S., Prior, R. 2004. Concentrations of proanthocyanidins in common foods and estimations of normal consumption. The Journal of Nutrition, 134, 613-7. 
Han, X., Shen, T., Lou, H. 2007. Dietary Polyphenols and Their Biological Significance. International Journal of Molecular Sciences, 8, 950-988.

Hansen, H.S. 1994. New biological and clinical roles for the n-6 and n-3 fatty acids. Nutrition Reviews, 52(5), 162-167.

Harborne, J.W. 2000. Advances in flavonoid research since 1992. Phytochemistry, 55, 481504.

Hasler, C. 1998. Functional foods their role in disease prevention and health promotion Food Technology, 52(2), 57-62.

Hathcock, J.N. 1997. Vitamins and minerals: efficacy and safety. The American Journal of Clinical Nutrition, 66(2), 427-437.

Henley, E.C., Taylor, J.R.N., Obukosia, S.D., 2010. The importance of dietary protein in human health: combating protein deficiency in sub-Saharan Africa through transgenic biofortified sorghum. In Advances in Food and Nutrition Research, Taylor, S.L. (Ed.), Academic Press, San Diego.

Hiemori, M., Koh, E.; Mitchell, A.E., 2009. Influence of Cooking on Anthocyanins in Black Rice (Oryza sativa L. japonica var. SBR). Journal of Agricultural and Food Chemistry. 57, 1908-1914.

Hoi, J.T., Weller, C.L., Schlegel, V.L., Cuppett, S.L., Lee, J.-Y., Carr, T.P. 2009. Sorghum distillers dried grain lipid extract increases cholesterol excretion and decreases plasma and liver cholesterol concentration in hamsters. Journal of Functional Foods, 1(4), $381-386$

Hooper, L., Abdelhamid, A., Bunn, D., Brown, T., Summerbell, C.D., Skeaff, C.M. 2015. Effects of total fat intake on body weight. Cochrane Database Syst Rev. 8:CD011834.

Howlett, J. 2008. Functional foods: from science to health and claims. ILSI Europe.

Ihnat, M. 2003. A survey of methods of analysis for minerals in feedstuffs. Journal of Animal Science, 81, 3218-3225.

Jiménez-Colmenero, F. 2007. Healthier lipid formulation approaches in meat-based functional foods. Technological options for replacement of meat fats by non-meat fats. Trends in Food Science \& Technology, 18(11), 567-578.

Khan, I., Yousif, A.M., Johnson, S.K., Gamlath, S., 2015. Acute effect of sorghum flourcontaining pasta on plasma total polyphenols, antioxidant capacity and oxidative stress markers in healthy subjects: a randomised controlled trial. Clinical Nutrition, 34(3), 415-421.

Khoddami, A., Truong, H.H., Liu, S.Y., Roberts, T.H., Selle, P.H. 2015. Concentrations of specific phenolic compounds in six red sorghums influence nutrient utilisation in broiler chickens. Animal Feed Science and Technology, 210, 190-199.

Kil, H.Y., Seong, E.S., Ghimire, B.K., Chung, I.-M., Kwon, S.S., Goh, E.J., Lee, D. 2009. Antioxidant and antimicrobial activities of crude sorghum extract. Food Chemistry, 115(4), 1234-1239.

Kim, J., Park, Y. 2012. Anti-diabetic effect of sorghum extract on hepatic gluconeogenesis of streptozotocin-induced diabetic rats. Nutrition \& Metabolism, 9(1), 106.

Kim, J.-S., Hyun, T. K., Kim, M.-J. 2011. The inhibitory effects of ethanol extracts from sorghum, foxtail millet and proso millet on $\alpha$-glucosidase and $\alpha$-amylase activities. Food Chemistry, 124(4), 1647-1651. 
Kolanowski, W., Laufenberg, G. 2006. Enrichment of food products with polyunsaturated fatty acids by fish oil addition. European Food Research and Technology, 222(3-4), 472-477.

Leder, I. 2004. Sorghum and millets. In Cultivated plants, primarily as food sources. G. Fuleky (Ed.), Oxford, UK: Eolss Publishers.

Martinez, I., Wallace, G., Zhang, C., Legge, R., Benson, A. K., Carr, T.P., Walter, J. 2009. Diet-induced metabolic improvements in a hamster model of hypercholesterolemia are strongly linked to alterations of the gut microbiota. Applied and Environmental Microbiology, 75(12), 4175-4184.

McCarty, M.F. 2005. Magnesium may mediate the favorable impact of whole grains on insulin sensitivity by acting as a mild calcium antagonist. Medical Hypotheses, 64, 619. 627.

Mehta, R. 2005. Dietary fiber benefits. Cereal Foods World, 50, 66-71.

Miafo, A.P.T., Koubala, B.B., Kansci, G., Saha, B.U.F., Fokou, E. 2015. Optimizing the extraction of dietary fibers from sorghum bran using response surface methodology. Journal of Food Processing, 2015.

Murano, P.S 2003. Understanding Food Science and Technology. Australia: Thomson learning Inc.

Nguni, D., Geleta, M., Johansson, E., Fatih, M., Bryngelsson, T. 2011. Characterization of the Southern African sorghum varieties for mineral contents: Prospects for breeding for grain mineral dense lines. African Journal of Food Science, 5(7), 436-445

Opopol, N., Obreja, O., Ciobanu, A. 2006. Nutriţia în sănătatea publică. Casa editorialpoligrafică Bons Offices, Chişinău.

Ozen, A.E., Pons, A., Tur, J.A. 2012. Worldwide consumption of functional foods: A systematic review. Nutrition Reviews, 70(8), 472-81.

Paul, C., Leser, S., Oesser, S. 2019. Significant amounts of functional collagen peptides can be incorporated in the diet while maintaining indispensable amino acid balance. Nutrients, 11(5), 1079.

Ragaee, S., Abdel-Aal, E.M., Noaman, M. 2006. Antioxidant activity and nutrient composition of selected cereals for food use. Food Chemistry, 98(1), 32-38.

Rand, W.M., Pellett, P.L., Young, V.R. 2003. Meta-analysis of nitrogen balance studies for estimating protein requirements in healthy adults. The American Journal of Clinical Nutrition, 77(1), 109-127.

Rao, S., Santhakumar, A.B., Chinkwo, K.A., Wu, G., Johnson, S.K., \& Blanchard, C.L. 2018. Characterization of phenolic compounds and antioxidant activity in sorghum grains. Journal of Cereal Science, 84, 103-111.

Ratnavathi, C.V., Patil, J.V. 2013. Sorghum utilization as food. Nutrition \& Food Sciences, 4(1), 1-8.

Regulation (EU) no 1169/2011 of the European Parliament and of the Council of 25 October 2011 on the provision of food information to consumers https://eurlex.europa.eu

Roberfroid, M.B. 2000. Defining functional foods. In Functional foods, 9, Gibson, G.R., Williams, C.M. Woodhead Publishing Limited. 
Rooney, L.W., Waniska, R.D. 2000. Sorghum food and industrial utilization. In Sorghum: Origin, history, technology, and production. Smith C.W., Frederiksen R.A. (Eds.), John Wiley \& Sons.

Rooney, T.K., Rooney, L.W., Lupton, J.R. 1992. Physiological characteristics of sorghum and millet brans in the rat model. Cereal foods world (USA).

Rubio-Rodríguez, N., Beltrán, S. Jaime, I., Sara, M., Sanz, M.T., Carballido, J.R. 2010. Production of omega-3 polyunsaturated fatty acid concentrates: a review. Innovative Food Science \& Emerging Technologies, 11(1), 1-12.

Saghiri, M.A., Asatourian, A., Ershadifar, S., Moghadam, M.M., Sheibani, N. 2017. Vitamins and regulation of angiogenesis: [A, B1, B2, B3, B6, B9, B12, C, D, E, K]. Journal of Functional Foods. 38, 180-196.

Scientific Concepts of Functional Foods in Europe, http://www.ilsi.org/Europe/Pages/FUFOSE.aspx.

Segal, R. 2002. Principiile nutriției, Editura Academica, Galaţi.

Serna-Saldivar, S., Rooney, L.W., 1995. Structure and chemistry of sorghum and millets. In: Structure and Chemistry of Sorghum and Millets, Dendy, D.A.V. (Ed.). American Association of Cereal Chemists.

Shalaby, E.A., Shanab, S.M. 2013. Antioxidant compounds, assays of determination and mode of action. African Journal of Pharmacy and Pharmacology, 7(10), 528-539.

Shang, N., Chaplot, S., Wu, J. 2018. Food proteins for health and nutrition. In Proteins in food processing, Yada, R.Y., Woodhead Publishing.

Sharanya Rani, D., Penchalaraju, M. 2016. A review different types of functional foods and their health benefits. International Journal of Applied and Natural Sciences, 5(3), 1928.

Shen, S., Huang, R., Li, C., Wu, W., Chen, H., Shi, J., Ye, X. 2018. Phenolic compositions and antioxidant activities differ significantly among sorghum grains with different applications. Molecules, 23(5), 1203.

Sinha, R., Patterson, B.H., Mangels, A.R., Levander, O.A., Gibson, T., Taylor, P.R., Block, G. 1993. Determinants of plasma vitamin E in healthy males. Cancer Epidemiology and Prevention Biomarkers, 2(5), 473-479.

Spotti, M.J., Campanella, O.H. 2017. Functional modifications by physical treatments of dietary fibers used in food formulations. Current Opinion in Food Science. 15, 70-78.

Suganyadevi, P., Saravanakumar, K., Mohandas, S. 2013. The antiproliferative activity of 3-deoxyanthocyanins extracted from red sorghum (Sorghum bicolor) bran through P53dependent and Bcl-2 gene expression in breast cancer cell line. Life Sciences, 92, 379382 .

Svensson, L., Sekwati-Monang, B., Lutz, D.L., Schieber, A., Ganzle, M.G. 2010. Phenolic acids and flavonoids in nonfermented and fermented red sorghum (Sorghum bicolor (L.) Moench). Journal of Agricultural and Food Chemistry, 58(16), 9214-9220.

Taylor, J.R., Belton, P.S., Beta, T., Duodu, K.G. 2014. Increasing the utilisation of sorghum, millets and pseudocereals: Developments in the science of their phenolic phytochemicals, biofortification and protein functionality. Journal of Cereal Science, 59(3), 257-275. 
Tsao, R. 2010. Chemistry and biochemistry of dietary polyphenols, Nutrients, 2, 12311246.

USDA, 2019. https://fdc.nal.usda.gov/

Vanamala, J.K.P., Massey, A.R., Pinnamaneni, S.R., Reddivari, L., Reardon, K.F. 2018. Grain and sweet sorghum (Sorghum bicolor L.Moench) serves as a novel source of bioactive compounds for human health. Critical Reviews in Food Science and Nutrition, 58(17), 2867-2881.

Wang, C., Li, S. 2014. Functional foods and nutraceuticals: potential role in human health. In Clinical aspects of functional foods and nutraceuticals. Ghosh D., Bagchi D., Konishi T., CRC Press.

Wolfe, R.R., Cifelli, A.M., Kostas, G., Kim, I.Y. 2017. Optimizing protein intake in adults: interpretation and application of the recommended dietary allowance compared with the acceptable macronutrient distribution range. Advances in Nutrition, 8(2), 266-275.

Wu, X., Beecher, G.R., Holden, J. M., Haytowitz, D.B., Gebhardt, S.E., Prior, R.L. 2004. Lipophilic and hydrophilic antioxidant capacities of common foods in the United States. Journal of Agricultural and Food Chemistry, 52(12), 4026-4037.

Xiong, Y., Zhang, P., Warner, R. D., Fang, Z. 2019. Sorghum grain: from genotype, nutrition, and phenolic profile to its health benefits and food applications. Comprehensive Reviews in Food Science and Food Safety, 2025-2046

Yang, L.Y., Browning, J.D., Awika, J.M. 2009. Sorghum 3-deoxyanthocyanins possess strong phase II enzyme inducer activity and cancer cell growth inhibition properties. Journal of Agricultural and Food Chemistry, 57, 1797-1804.

Yu, L., Nanguet, A.L. 2013. Comparison of antioxidant properties of refined and whole wheat flour and bread. Antioxidants, 2, 370-383. 